\title{
Tinjauan Yuridis Mengenai Dampak COVID-19 Terhadap Pemutusan Hubungan Kerja
}

\author{
Juridical Review of the Impact of COVID-19 on Termination of Employment
}

\author{
Herman', Wahyu Aliansa², \\ Andrean Gregorius Simamora ${ }^{3}$, Nadilla Mayang Chahyani ${ }^{4}$ \\ 1. Universitas Halu Oleo, Indonesia, herman.man76@gmail.com \\ 2. Universitas Airlangga, Indonesia, wahyu.aliansa@gmail.com \\ 3. Universitas Airlangga, Indonesia, Sandreangregorius@yahoo.com \\ 4. Universitas Airlangga, Indonesia, nadilla.mayang.chahyani-2018@fh.unair.ac.id
}

\begin{tabular}{l}
\hline ARTICLE INFO \\
\hline Keywords: \\
COVID-19; \\
Force Majeure; \\
Hardship; \\
Work Termination \\
\end{tabular}

\section{INFO ARTIKEL}

Kata kunci:
COVID-19;
Force Majeure;
Hardship;
PHK

\begin{abstract}
The spread of the COVID-19 virus has grown rapidly in recent months in the world, including Indonesia, therefore, the government urges learning, worship, and work to be carried out in their respective homes to prevent the spread of COVID-19. This government policy eventually led to several companies on the ground. Air chose to terminate employment which resulted in many employees feeling disadvantaged. In this scientific paper the author uses empirical normative legal research methods in resolving the impact of COVID-19 on termination of employment. In this regard, the role of the government is urgently needed to provide solutions by creating legal certainty so that neither party is harmed. In Law No. 13 of 2003 concerning Manpower itself does not explain in detail whether an outbreak or a pandemic disease is currently in a state of forcing "force majeure", with the ambiguity of Law no. 13 of 2003, the government in providing legal certainty issued Presidential Decree 12 of 2020 concerning the Determination of Non-Natural Disasters for the spread of COVID-19 as a national disaster. However, the issuance of Presidential Decree 12/2020 does not provide legal certainty but raises many questions whether this termination includes "FORCE MAJEUR" or "HARDSHIP.
\end{abstract}

\begin{tabular}{l} 
ABSTRAK \\
Penyebaran virus COVID-19, telah berkembang pesat dalam beberapa bulan \\
ini di dunia termasuk Indonesia oleh sebab itu, pemerintah menghimbau agar \\
belajar, ibadah, dan bekerja dilakukan di rumah masing-masing untuk \\
mencegah penyebaran COVID-19. Kebijakan pemerintah tersebut akhirnya \\
membuat beberapa perusahaan di tanah air memilih untuk melakukan \\
pemutusan hubungan kerja yang berakibat banyaknya karyawan merasa \\
dirugikan. Pada karya ilmiah ini penulis menggunakan metode penelitian \\
hukum normatif empiris dalam menyelesaikan dampak COVID-19 terhadap \\
pemutusan Hubungan Kerja. Sehubungan dengan hal ini peran pemerintah \\
sangat dibutuhkan untuk memberikan solusi dengan cara menciptakan \\
kepastian hukum agar tidak ada pihak yang dirugikan. Dalam Undang- \\
Undang No. 13 Tahun 2003 Tentang Ketenagakerjaan sendiri tidak \\
\hline
\end{tabular}


dijelaskan secara rinci apakah adanya wabah atau penyakit pandemi saat ini termasuk dalam keadaan memaksa "force majeur", dengan ketidakjelasan Undang-Undang No. 13 Tahun 2003 maka pemerintah dalam memberikan kepastian hukum menerbitkan Keppres 12 Tahun 2020 Tentang Penetapan Bencana Non Alam penyebaran COVID-19 sebagai bencana nasional. Tetapi dengan dibuatnya Keppres 12 Tahun 2020 ini bukannya memberikan kepastian hukum namun menimbulkan banyak pertanyaan apakah di dalam Pemutusan Hubungan Kerja ini termasuk "FORCE MAJEUR" atau "HARDSHIP".

\section{Pendahuluan}

Pada 31 Desember 2019, WHO China Country Office melaporkan kasus virus yang berada di kota Wuhan, provinsi Hubai, Cina. Tanggal 7 Januari 2020 Cina mengidentifikasi virus ini sebagai virus jenis baru yaitu coronavirus (Coronavirus Disease, COVID-19). ${ }^{1} 30$ Januari 2020 WHO telah menetapkan sebagai kedaruratan kesehatan masyarakat yang meresahkan dunia/public health emergency of international concerm (KKMD/PHIC). Dengan meningkatnya jumlah kasus COVID-19, yang berlangsung cukup cepat dan ditambah lagi penyebaran antar negara sampai dengan tanggal 3 Maret 2020 secara global dapat dilaporkan 90.870 kasus konfirmasi di 72 negara dengan 3.112 kematian. Berdasarkan penelitian ilmiah, COVID-19 menular dari manusia ke manusia melalui kontak erat dan lingkungan sekitar yang tercemar oleh virus. Orang yang paling berisiko tertular penyakit ini adalah kontak erat dengan pasien COVID $-19 .{ }^{2}$

Pada tanggal 11 Maret 2020 World Health Organization (WHO) akhirnya menyatakan COVID-19 sebagai global pandemik. Dengan pertimbangan ini dan berbagai pertimbangan lainnya Presiden Joko Widodo menetapkan coronavirus disease atau COVID-19 menjadi bencana nasional dengan mengeluarkan Keputusan Presiden Nomor 12 Tahun 2020 Tentang Penetapan Bencana Non alam Penyebaran Corona Virus Disease 2019 (COVID19) Sebagai Bencana Nasional (selanjutnya disebut Keppres 12/2020) pada 13 April 2020. Salah satu pertimbangan Presiden mengeluarkan Keppres 12/2020 adalah karena bencana non alam yang disebabkan oleh COVID-19 telah berdampak meningkatkan jumlah korban dan kerugian harta benda, meluasnya cakupan bencana serta menimbulkan implikasi sosial ekonomi yang meluas di wilayah Indonesia. Dengan adanya Keppres 12/2020 ini tentunya menimbulkan dampak bagi masyarakat Indonesia salah satunya di bidang ketenagakerjaan dikarenakan adanya Keppres ini banyak perusahaan yang menerapkan WFH (Work From Home) dan beberapa perusahaan juga melakukan

1 World Health Organization, "Naming the Coronavirus Disease (COVID-19) and the Virus that Causes It," World Health Organization, last modified 2020, diakses Mei 18, 2020, https://www.who.int/emergencies/diseases/novel-coronavirus-2019/technical-guidance/naming-thecoronavirus-disease-(covid-2019)-and-the-virus-that-causes-it.

2 Mela Arnani, "Timeline Wabah Virus Corona, Terdeteksi pada Desember 2019 hingga Jadi Pandemi Global," Kompas.com, last modified 2020, diakses Mei 18, 2020, https://www.kompas.com/tren/read/2020/03/12/113008565/timeline-wabah-virus-coronaterdeteksi-pada-desember-2019-hingga-jadi. 
pemutusan hubungan kerja terhadap karyawannya, dalam hal ini tentunya karyawan merasa dirugikan.

Perlu kita ketahui tenaga kerja yaitu pembangunan dan pelaku ekonomi baik secara individu maupun secara kelompok, sehingga mempunyai peranan yang sangat signifikan dalam aktivitas perekonomian nasional, yaitu meningkatnya produktivitas dan kesejahteraan masyarakat. Tenaga kerja Indonesia sendiri sebagai salah satu penggerak sumber daya yang jumlahnya cukup melimpah. Di Indonesia sendiri pengaturan mengenai pekerja diatur di dalam Undang-Undang Nomor 13 Tahun 2003 Tentang Ketenagakerjaan (selanjutnya disebut UU Ketenagakerjaan), salah satu aturan yang dijelaskan dalam undang-undang ini yaitu tentang pemutusan hubungan kerja. Akan tetapi dalam kenyataannya membuktikan bahwa pemutusan hubungan kerja tidak dapat dicegah seluruhnya.

Adapun alasan-alasan yang dipandang sebagai alasan yang cukup kuat untuk menunjang pembenaran PHK yang dilakukan oleh pengusaha atas diri seorang atau beberapa pekerja pada dasarnya ialah sebagai berikut: ${ }^{3}$

1. Alasan Ekonomis

a. Menurutnya hasil produksi yang dapat pula disebabkan oleh merosotnya kapasitas produksi perusahaan yang bersangkutan;

b. Merosotnya penghasilan perusahaan;

c. Merosotnya kemampuan perusahaan tersebut untuk membayar upah/gaji dalam keadaan yang sama dengan sebelumnya;

d. Pelaksanaannya rasionalisme atau penyederhanaan yang berarti pengurangan pekerja dalam jumlah besar dalam perusahaan yang bersangkutan.

2. Alasan tentang diri pribadi pekerja yang bersangkutan

a. Tidak memiliki kemampuan kerja dan prestasi memadai selaras dengan target yang telah ditentukan, meskipun berbagai usaha dan waktu yang diberikan untuk memberikannya sudah cukup banyak;

b. Tidak memiliki tingkah laku yang baik: tidak jujur, kurang mempunyai rasa tanggung jawab, sering mangkir tanpa alasan dll.

3. Tidak memiliki kekuatan jasmani yang sepadan dengan beratnya tugas yang diemban, dan sebagainya.

4. Karena meninggalnya pengusaha dan tidak ada ahli waris yang mampu melanjutkan hubungan kerja dengan pekerja yang bersangkutan.

Terjadinya pemutusan hubungan kerja yang disebabkan oleh wabah COVID-19 menimbulkan permasalahan baru. Permasalahan baru yang timbul adalah apakah diperbolehkan sebuah perusahaan melakukan PHK terhadap pekerjanya dengan alasan adanya pandemi COVID-19 ini, seperti yang dapat kita ketahui bahwa saat ini perusahaan di Indonesia kebanyakan melakukan PHK terhadap pekerjanya, padahal dalam UU Ketenagakerjaan sendiri mengatur bahwa PHK dapat dilakukan oleh perusahaan jika

3 Sudibyo Aji Narendra Buwana dan Mario Septian Adi Putra, "Implementasi Pemutusan Hubungan Kerja (PHK) Terhadap Pekerja Status Perjanjian Kerja Waktu Tertentu (PKWT) PADA PT X DI KOTA MALANG," Jurnal Studi Manajemen 9, no. 5 (2015): 202-214. 
perusahaan itu mengalami kerugian selama dua tahun berturut-turut, dan karena kesalahan dari pekerjanya sendiri, sedangkan PHK akibat pandemi ini sendiri dapat dikatakan bahwa PHK yang dilakukan tanpa adanya kesalahan dari Pekerjanya sendiri.

Apakah COVID-19 ini dapat digunakan sebagai alasan maupun penyebab dalam pemutusan hubungan kerja atau termasuk hardship.

\section{Metode}

Penulis menggunakan metode normatif dan empiris. Metode empiris yaitu metode mengenai pemberlakuan tentang ketentuan hukum normatif (kodifikasi, undang-undang, atau kontrak) secara in action pada setiap peristiwa hukum tertentu yang terjadi pada ruang lingkup masyarakat. ${ }^{4}$ Dengan menggunakan pendekatan statute approach atau pendekatan undang-undang. Menurut Soerjono Soekanto dan Sri Mamuji menjelaskan, bahwa penelitian hukum empiris atau sosiologi adalah penelitian hukum yang dilakukan dengan cara meneliti data primer. Data di dalam penelitian hukum empiris sendiri terdiri atas data primer dan data sekunder. Data primer metode pengumpulannya dilakukan dengan menggunakan observasi, wawancara, dan kuesioner, sedangkan untuk data sekunder metode pengumpulannya dilakukan dengan cara membaca di perpustakaan atau literatur, mengutip yang mempunyai hubungannya dengan permasalahan penelitian. Dalam karya tulis ilmiah ini menggunakan metode pengumpulan data sekunder, yang dimana menggunakan berbagai literatur seperti jurnal dan juga buku yang berkaitan tentang Pemutusan Hubungan Kerja, force majeur, dan hardship. ${ }^{5}$ Metode penelitian karya ilmiah normatif yaitu metode ilmiah yang menggunakan pendekatan berdasarkan dengan menelaah hal-hal yang bersifat teoritis yang mencakup asas-asas hukum, konsepsi hukum, pandangan dan tidak lupa juga doktrin-doktrin hukum. Penelitian karya ilmiah normatif yaitu sistem hukum dengan menggunakan sistem data sekunder, di antaranya asas, kaidah, norma dan aturan yang terdapat peraturan perundang-undangan dan aturan lainnya yang berkaitan dengan penelitian karya ilmiah ini. Dalam karya ilmiah ini, metode normatifnya terdapat dalam Undang-Undang Ketenagakerjaan, Keppres 2020, serta perbandingan force majeur dan hardship. ${ }^{6}$

\section{Pemutusan Hubungan Kerja Force Majeur atau Hardship}

\subsection{Keadaan yang dapat dikatakan sebagai force majeure atau hardship}

Dalam dunia kerja hubungan antara perusahaan dengan pekerja, merupakan sebuah hubungan yang harus dijaga keharmonisannya, sebuah perusahaan tidak akan bisa berjalan tanpa adanya pekerja, sebaliknya, pekerja juga membutuhkan perusahaan untuk menyalurkan tenaga, keahlian, ataupun pikirannya. Sehingga dalam hubungan perusahaan dan pekerja haruslah tercipta suatu hubungan yang saling menguntungkan. Sebelum

4 Abdulkadir Muhammad, Hukum dan Penelitian (Bandung: Citra Aditya Bakti, 2004), 134.

5 H. Ishaq, Metode Penelitian Hukum dan Penulisan Skripsi Tesis Serta Disertasi (Bandung: Alfabeta, 2017), 73.

6 Soerjono Soekanto, Penelitian Hukum Normatif (Jakarta: RajaGrafindo Persada, 2006), 24. 
membahas lebih dalam, tentu perlu diketahui siapa itu pekerja dan siapa itu perusahaan. Dalam Pasal 1 angka 6 Undang-Undang Nomor 13 Tahun 2003 Tentang Ketenagakerjaan menjelaskan yang dimaksud dengan Perusahaan adalah:

"a. Setiap bentuk usaha yang berbadan hukum atau tidak, milik orang perseorangan, milik persekutuan, atau milik badan hukum, baik milik swasta maupun milik negara yang memperkerjakan pekerja/buruh dengan membayar upah atau imbalan dalam bentuk lain;

b. Merupakan suatu jenis usaha-usaha sosial maupun usaha-usaha lain yang mempunyai struktural organisasi yakni pengurus dan sumber daya manusia dengan membayar upah atau imbalan dalam bentuk lain."

Sedangkan yang dimaksud dengan pekerja sebagaimana disebutkan dalam pasal 1 angka 3 UU 13/2003 adalah:

"setiap masyarakatyang bekerja dengan menerima upah atau imbalan dalam bentuk lain".

Dalam memulai hubungan kerja ini perusahaan dengan pekerja membuat sebuah perjanjian, dalam hal ini disebut dengan perjanjian buruh. Perjanjian buruh ini diatur dalam KUHPerdata lebih tepatnya pada Pasal 1601 huruf d sampai Pasal 1601 huruf i. Dalam pasal-pasal tersebut terdapat beberapa ketentuan dalam perjanjian perburuhan yaitu:

1. Suatu perjanjian perburuhan yang dibuat secara tertulis maka biaya akta dan biaya tambahan lainnya dibebankan kepada majikan.

2. Apabila pada saat dibuat perjanjian perburuhan diberikan dan diterima uang panjar maka tidak ada satu pihak pun berhak meminta untuk dikembalikan karena meniadakan perjanjian. Tetapi uang panjar hanya dapat dikurangkan dari upah jika hubungan kerja telah berlangsung.

3. Apabila perjanjian perburuhan dibuat oleh seorang perempuan yang sudah bersuami sebagai buruh maka undang-undang menganggap bahwa ia sudah mendapatkan izin dari suaminya.

4. Apabila seseorang belum cakap melakukan perjanjian perburuhan sebagai buruh dianggap cakap jika dikuasakan oleh wakilnya menurut undang-undang baik lisan maupun tertulis. Tetapi, apabila dia belum cakap melakukan perjanjian perburuhan dan selama enam minggu telah melakukan pekerjaan serta tiada perlawanan dari pihak wakilnya menurut undang-undang maka dianggap telah dikuasakan dengan lisan.

5. Suatu perjanjian perburuhan antara suami istri adalah batal.

Tidak hanya dalam KUHPerdata, Undang-Undang Nomor 13 Tahun 2003 Tentang Ketenagakerjaan juga mengatur perjanjian antara perusahaan dengan pekerja salah satunya perjanjian kerja yang dijelaskan pada Pasal 50 sampai dengan pasal 63 UndangUndang Nomor 13 Tahun 2003 Tentang Ketenagakerjaan. Dalam Pasal 52 ayat (1) disebutkan bahwa Perjanjian kerja dapat dibuat dengan dasar: 
1. Kesepakatan kedua belah pihak;

2. Kemampuan atau kecakapan melakukan perbuatan hukum;

3. Adanya pekerjaan yang diperjanjikan; dan

4. Pekerjaan yang ditujukan kepada para pekerja untuk dikerjakan tidak boleh bertentangan dengan ketertiban umum, kesusilaan, dan sesuai dengan prosedur sebagaimana dijelaskan oleh peraturan perundang-undangan yang berlaku.

Perjanjian kerja ini berakhir jika terjadi Pemutusan Hubungan Kerja yang merupakan suatu hal yang terpenting bagi buruh dalam masalah perburuhan. Sebagaimana disebutkan Iman Soepomo bahwa berakhirnya hubungan kerja bagi buruh berarti kehilangan mata pencaharian, merupakan permulaan dari segala kesengsaraan, berdasarkan teori memang buruh berhak pula untuk mengakhiri hubungan kerja, tetapi dalam kehidupan sehari-hari pengusaha yang mengakhirinya bila ada sebab atau permasalahan tertentu, sehingga yang melakukan pengakhiran itu selalu merupakan pengakhiran hubungan kerja oleh pihak majikan atau pengusaha lebih tepatnya. ${ }^{7}$ Pengertian dari Pemutusan Hubungan Kerja sendiri dijelaskan dalam Keputusan Menteri Tenaga Kerja Republik Indonesia Nomor 150 Tahun 2000 yaitu pengakhiran hubungan kerja antara pengusaha dengan pekerja berdasarkan ijin panitia daerah atau panitia pusat. Pemutusan Hubungan Kerja sendiri lebih jelasnya diatur dalam UU Ketenagakerjaan dalam Undang-Undang ini disebutkan beberapa akibat suatu perusahaan dapat melakukan Pemutusan Hubungan Kerja kepada pekerja. Dalam karya tulis ilmiah ini akan menganalisis tentang Pemutusan Hubungan Kerja akibat pandemi COVID-19.

Berbicara mengenai aturan, hardship menentukan bahwa apabila pelaksanaan kontrak menjadi lebih berat bagi salah satu pihak, pihak tersebut bagaimanapun juga terikat melaksanakan perikatannya dengan tunduk pada ketentuan mengenai hardship, persoalan ini diatur oleh Pasal 6.2.1 UPICC, tentang (Contract to be observed-kontrak yang harus dipatuhi). Ketentuan ini menjelaskan dua hal pokok, yaitu:

a. Sifat mengikat dari kontrak sebagai aturan umum (binding character of the contract the general rule).

Tujuan dari aturan umum bertujuan untuk mempertegas bahwa kontrak itu mengikat untuk dilaksanakan asal dimungkinkan, tanpa memperhatikan beban yang dipikul oleh pihak yang melaksanakan. Meskipun beberapa dari pihak-pihak yang mengalami kerugian besar atau pelaksanaan kontrak menjadi tidak bermakna bagi pihak lain, bagaimanapun kontrak tersebut harus tetap dihargai.

b. Perubahan keadaan yang relevan hanya terkait kontrak-kontrak tertentu (kontrak yang pelaksanaannya belum dilakukan atau masih berlaku dan berjangka panjang). Prinsip sifat mengikatnya kontrak tidaklah bersifat absolut, apabila dalam hal terjadi keadaan yang menimbulkan perubahan fundamental terhadap keseimbangan dari kontrak. Keadaan tersebut merupakan situasi yang dikecualikan.

7 Iman Soepomo, Pengantar Hukum Perburuhan (Jakarta: Djambatan, 1999), 88. 
Force Majeur tidak bisa secara cepat atau dalam arti serta merta dijadikan alasan pembatalan kontrak juga dalam arti pembatalan kontrak dengan alasan force majeur tergantung pada isi klausul yang terkandung dalam kontrak tersebut. Artinya harus dilihat dulu apakah di dalam klausul kontrak tersebut ada kesepakatan bahwa jika terjadi force majeur isi kontrak bisa disimpangi. Jadi harus ada klausul dalam kesepakatan itu. Itu pun harus dilihat pula pada jenis force majeur yang terjadi yang juga dicantumkan dalam klausul kontrak, apakah dalam hal tersebut termasuk force majeur absolut atau force majeur relatif. Force majeur absolut adalah kejadian yang secara mutlak meniadakan kemampuan pihak untuk memenuhi prestasinya seperti musnahnya bangunan yang dijadikan jaminan kontrak karena bencana alam yang menyebabkannya ambles dan hilang seperti gempa yang terjadi di Palu pada tahun 2018 yang menyebabkan adanya rumahrumah dan hotel berbintang lenyap ditelan bumi. Force majeur relatif adalah force majeur yang mengubah keadaan tetapi masih ada alternatif-alternatif atau jalan keluar penyelesaian masalah yang dapat disubstitusikan, dikompensasi, ditunda, dan sebagainya seperti terhalangnya penyampaian barang karena alat transportasi yang membawanya mengalami kecelakaan. ${ }^{8}$ Terjadinya peristiwa berupa force majeure dalam bentuk ketidakmungkinan (impossibility) untuk melaksanakan prestasi adalah dalam hal sama sekali dalam keadaan apa pun pihak debitur tidak mungkin lagi memenuhi prestasinya. Misalnya, dalam hal perjanjian jual beli rumah, dimana rumah tersebut terbakar sebelum sempat diserahkan ke tangan pembeli, tetapi kebakaran tersebut bukan karena kesalahan pemiliknya. ${ }^{9}$ Dalam perspektif Hukum Perikatan, dalil keadaan memaksa yang diajukan oleh debitur terkait dengan tidak dipenuhinya suatu perikatan. Oleh sebab itu klausul keadaan memaksa hanya relevan untuk executory contract dan tidak untuk executed contract. Penerapan keadaan memaksa pada umumnya dikaitkan dengan jenis kontrak yang mengutamakan hasil (resutaat verbintenis) dan kontrak yang mengutamakan usaha dari debitur (inspanning verbintenis). Jika pada jenis yang pertama kreditor perlu membuktikan bahwa debitur tidak, mendatangkan hasil (resutaat) dari kontrak yang disepakati maka dalam jenis yang kedua debitur membuktikan bahwa debitur tidak cukup berusaha dalam melaksanakan kewajiban kontraktualnya. Namun demikian tidak ada batas yang jelas mengenai perbedaan dua jenis perikatan ini. Pembedaan dua jenis perikatan ini lebih mudah dipahami jika dilihat dari segi prestasinya. Prestasi pada jenis yang pertama pada umumnya adalah memberikan sesuatu dan berbuat sesuatu, sedangkan pada jenis yang kedua prestasi dalam bentuk berbuat sesuatu baik yang prestasinya dapat diganti atau tidak. Dalam perikatan dengan prestasi tidak berbuat sesuatu tidak dikenal keadaan memaksa.

Yang membedakan hardship dan force majeur ialah hardship lebih mengarah kepada situasi maupun keadaan yang tidak proporsional atau tidak seimbang antara pihak yang melakukan suatu kesepakatan dalam perjanjian tetapi force majeur mempunyai makna dan artian yang lebih khusus mengarah pada peristiwa yang secara mendadak atau tidak

8 Munir Fuady, Konsep Hukum Perdata (Jakarta: Rajawali Pers, 2015), 271.

9 Yohanes Sogar Simamora, Prinsip-prinsip Hukum Kontrak Pengadaan Barang dan Jasa Pemerintah di Indonesia (Yogyakarta: Laksbang Pressindo, 2017), 286. 
terduga muncul di luar kekuasaan para pihak yang melakukan perjanjian. Sesuai penjelasan terkait force majeur yang sudah di jelaskan pada paragraf ke 5, pengaturan mengenai force majeur diatur oleh Jasa Konstruksi, Perbankan. Tetapi hanya saja ketentuan penjelasan mengenai force majeur di dalam peraturan perbankan tidak terkoneksi dengan kontrak maupun perjanjian. Unsur-unsur force majeur dalam suatu perjanjian antara lain:

a. Adanya kejadian di luar kemampuan atau kendali para pihak dalam melakukan perjanjian.

b. Terjadinya kerugian bagi para pihak dalam pelaksanaan suatu perjanjian.

c. Adanya peristiwa yang mengakibatkan tertunda dan situasi yang menghambat sehingga tidak terpenuhinya prestasi para pihak yang terlibat dalam kontrak perjanjian.

Contoh ilustrasi kasus force majeur antara lain mengenai kontrak jasa pengiriman barang, Arfie harus mengirim barang kepada Aliansa, namun karena ada bencana alam di kota Valen dimana Arfie harus melewati kota Valen untuk sampai ke kota Aliansa. Maka pengiriman barang menjadi tidak tepat waktu dan terpenuhinya unsur force majeur sebagai alasan permasalahan kasus.

Hardship adalah suatu situasi dimana kinerja dalam suatu pelaksanaan perjanjian menjadi lebih rumit dan berat bagi salah satu pihak, pihak yang tetap terikat pelaksanaan kewajibannya dalam perjanjian. Unsur-unsur hardship dalam suatu perjanjian antara lain:

a. Adanya kejadian tersebut di luar kontrol dari adanya pihak yang dirugikan dalam perjanjian.

b. Risiko dari kejadian permasalahan tersebut tidak diperkirakan oleh pihak yang dirugikan Berikut adalah tabel penjelasan perbedaan dari hardship dan force majeur di bawah:

\begin{tabular}{|c|c|c|c|}
\hline No. & Perbedaan & Hardship & Force majeur \\
\hline 1. & $\begin{array}{l}\text { Dasar } \\
\text { hukum }\end{array}$ & $\begin{array}{l}\text { Belum diatur dalam KUHPer. tapi sudah diatur } \\
\text { dalam RUU tentang kontrak (ELIPS) dan pasal } \\
6.2 .2 \text { UPICC }\end{array}$ & $\begin{array}{l}\text { Pasal 1244, 1245, 1444, } 1445 \\
\text { KUHPer }\end{array}$ \\
\hline 2. & Penyebab & $\begin{array}{l}\text { Ditentukan pada peristiwa mengubah } \\
\text { keseimbangan pada suatu kontrak secara } \\
\text { fundamental baik karena biaya atau nilai } \\
\text { pelaksanaannya yang berubah signifikan } \\
\text { sehingga dapat menimbulkan kerugian yang } \\
\text { tidak wajar pada pihak. Yang dimaksud } \\
\text { peristiwa di sini adalah peristiwa non alam, } \\
\text { Peristiwa non alam adalah bencana yang } \\
\text { diakibatkan oleh peristiwa atau rangkaian } \\
\text { peristiwa non alam yang antara lain berupa } \\
\text { epidemi, dan wabah penyakit. }\end{array}$ & $\begin{array}{l}\text { Terjadi karena bencana alam, } \\
\text { darurat, dan keadaan memaksa }\end{array}$ \\
\hline 3. & $\begin{array}{l}\text { Negosiasi } \\
\text { kontrak }\end{array}$ & $\begin{array}{l}\text { Kontrak dapat di negosiasi ulang oleh para } \\
\text { pihak. Perikatan tidak langsung terhapus }\end{array}$ & $\begin{array}{l}\text { Kontrak berakhir dan tidak dapat } \\
\text { dilakukan negosiasi ulang. } \\
\text { Merujuk pada } 1381 \text { KUHPer, } \\
\text { maka force majeur merupakan }\end{array}$ \\
\hline
\end{tabular}




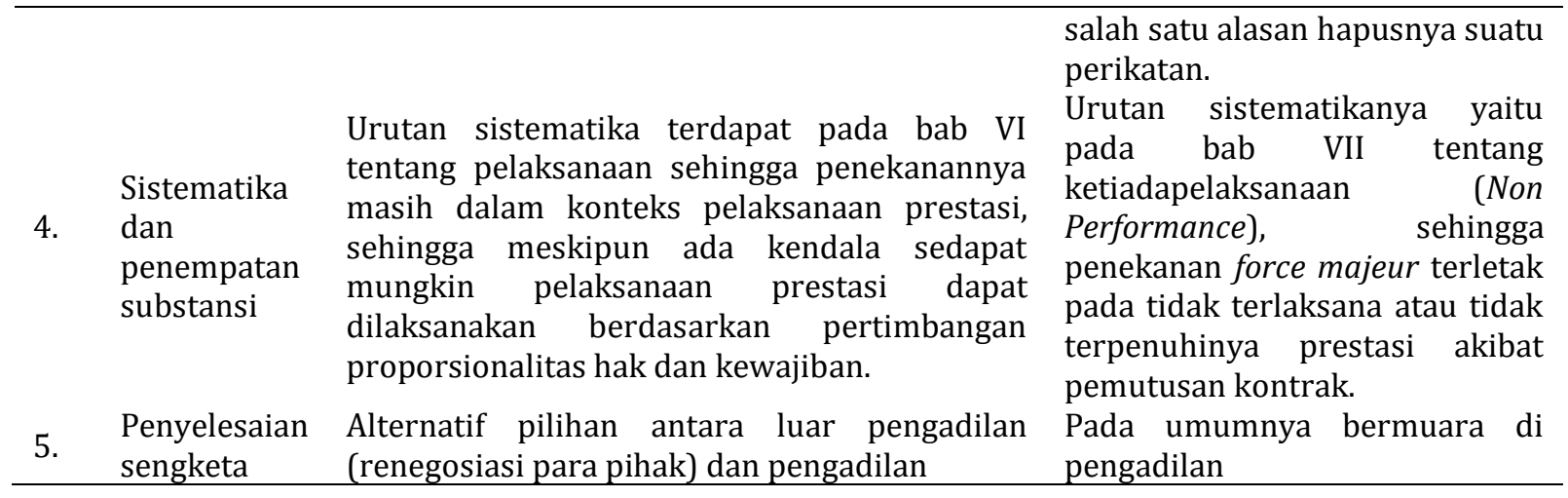

Berpijak dari definisi hardship yang diberikan oleh UNIDROIT Principles tersebut di atas beserta empat persyaratannya, maka setidaknya terdapat 3 (tiga) unsur untuk menentukan ada atau tidaknya hardship yaitu: 10

1. Perubahan keseimbangan kontrak secara fundamental (fundamental alteration of equilibrium of the contract);

2. Meningkatnya biaya pelaksanaan kontrak (increase in cost of performance);

3. Menurunnya nilai pelaksanaan kontrak yang diterima salah satu pihak (decrease in value of the performance received by one party);

\subsection{Pemutusan hubungan kerja pada masa COVID-19 sesuai dengan ketentuan hardship}

Pengertian Perjanjian, sebagaimana diatur dalam Pasal 1313 KUHPer adalah Suatu perbuatan dengan mana satu orang atau lebih mengikatkan dirinya pada satu orang atau lebih lainnya. Perjanjian yang dibuat oleh para pihak baik secara lisan maupun tertulis perlu mengindahkan asas-asas hukum perjanjian, peraturan-peraturan hukum yang terkait dengan perjanjian. ${ }^{11}$ Dengan demikian perjanjian itu menerbitkan suatu perikatan bagi yang membuatnya. Perikatan sendiri adalah suatu perhubungan hukum antara dua orang atau dua pihak, berdasarkan yang mana pihak satu berhak menuntut sesuatu hal dari pihak yang lain, dan pihak yang lain berkewajiban untuk memenuhi tuntutan itu. Maka hubungan hukum antara perikatan dan perjanjian adalah bahwa perjanjian itu menerbitkan perikatan. Dalam Hukum Ketenagakerjaan sendiri terdapat perjanjian, yang biasa disebut dengan perjanjian kerja. Perjanjian kerja adalah merupakan awal dari terbentuknya sebuah hubungan kerja. Hubungan antara pengusaha dan pekerja akan terjadi setelah adanya suatu perjanjian kerja. Dalam Pasal 1 Angka 14 Undang-Undang No.13 Tahun 2003 Tentang Ketenagakerjaan dijelaskan bahwa yang dimaksud dengan perjanjian kerja adalah perjanjian antara pekerja dengan pengusaha ataupun pemberi

10 Dwi Prilmilono Adi, "Absorbsi Prinsip 'Rebus Sic Stantibus' dalam Kerangka Pembaharuan Hukum Perjanjian Nasional," Jurnal Hukum Jatiswara (2015): 71.

11 Ery Agus Priyono, "Aspek Keadilan dalam Kontrak Bisnis di Indonesia (Kajian pada Perjanjian Waralaba)," Law Reform 14, no. 1 (2018): 15-28. 
kerja yang memuat syarat-syarat kerja, hak dan kewajiban para pihak. ${ }^{12}$ Perjanjian kerja tidak dimintakan bentuk tertentu, dapat dilakukan secara lisan dengan surat pengangkatan oleh pihak pengusaha atau secara tertulis, perjanjian kerja yang harus diadakan secara tertulis, hanya memuat: ${ }^{13}$
a. Macam pekerjaan;
b. Lamanya perjanjian itu berlaku;
c. Besarnya upah sebulannya.
d. Lamanya waktu istirahat.

Dalam Pemutusan Hubungan Kerja sendiri terbagi menjadi 4 jenis yaitu, Pemutusan Hubungan Kerja demi hukum, Pemutusan Hubungan Kerja yang dilakukan oleh pekerja, Pemutusan Hubungan Kerja oleh Pengadilan, dan yang terakhir Pemutusan Hubungan Kerja oleh pengusaha. ${ }^{14}$

Jenis pertama adalah Pemutusan Hubungan Kerja (PHK) demi hukum yang diatur dalam Pasal 154 UU Ketenagakerjaan, yang dimana PHK demi hukum ini terjadi jika pekerja masih dalam masa percobaan kerja, pekerja mengajukan permintaan pengunduran diri, pekerja mencapai usia pensiun, dan pekerja meninggal dunia.

Jenis kedua yakni PHK yang dilakukan oleh pekerja, menurut teori yang timbul akibat adanya pandangan dunia barat bahwa kepada pekerja harus diberikan hak yang sama dalam hukum, jika pengusaha mempunyai hak untuk mengakhiri hubungan kerja, maka pekerja juga memiliki hak tersebut. ${ }^{15}$ Pemutusan Hubungan Kerja (PHK) sejenis ini lebih lanjut diatur dalam Pasal 154 huruf b UU Ketenagakerjaan yang berbunyi:

"Penetapan sebagaimana dimaksud dalam Pasal 151 ayat (3) tidak diperlukan dalam hal:

b. Pekerja/buruh mengajukan permintaan pengunduran diri, secara tertulis atas kemauan sendiri tanpa ada indikasi adanya tekanan/intimidasi dari pengusaha, berakhirnya hubungan kerja sesuai dengan perjanjian kerja waktu tertentu untuk pertama kali".

Adapun alasan mendesak yang mengakibatkan bahwa dari pihak pekerja adalah tidak layak mengharapkan untuk meneruskan hubungan kerja. Alasan mendesak itu antara lain: 16

12 Abdul Hadi, "Fenomena Menikah Dengan Teman Sekantor Pasca Putusan Mahkamah Konstitusi Tentang Uji Materi Pasal 153 Ayat (1) Huruf F Undang-Undang Nomor 13 Tahun 2003 Tentang Ketenagakerjaan," Jurnal Surya Kencana Dua: Dinamika Masalah Hukum dan Keadilan 5, no. 1 (2018): 352-368.

13 Lanny Ramly, Hukum Ketenagakerjaan (Surabaya: Airlangga University Press, 2008), 28.

14 Umar Kasim, "Hubungan Kerja dan Pemutusan Hubungan Kerja," Informasi Hukum, last modified 2004, $\begin{array}{lll}\text { diakses } & \text { Agustus } & 10,\end{array}$ http://web.archive.org/web/20041230083336/http://www.nakertrans.go.id/majalah_buletin/info_hu kum/vol2_vi_2004/phk.php.

15 Ramly, Hukum Ketenagakerjaan, 42.

16 Y. W. Sunindhia dan Ninik Widiyanti, Masalah Pemutusan Hubungan Kerja dan Mogok (Jakarta: Bina Aksara, 1996), 58-59. 
1. Apabila majikan menganiaya, menghina secara kasar atau melakukan ancaman rumah tangga pekerja, atau membiarkan tindakan semacam itu dilakukan oleh anggota rumah tangga atau pekerja bawahan majikan;

2. Apabila majikan membujuk atau mencoba membujuk pekerja, anggota keluarga atau anggota rumah tangga pekerja untuk melakukan perbuatan yang bertentangan dengan Undang-Undang atau dengan tata susila atau membiarkan pembujukan atau percobaan pembujukan semacam itu dilakukan oleh anggota rumah tangga atau pekerja bawahan majikan;

3. Apabila majikan tidak membayar upah pada waktunya;

4. Apabila majikan tidak memenuhi secara layak makan dan pemondokan seperti yang dijanjikan;

5. Apabila majikan tidak memberi cukup pekerjaan kepada pekerja yang upahnya ditetapkan berdasarkan hasil pekerjaan yang dilakukannya;

6. Apabila majikan tidak memberi atau cukup memberi bantuan yang diperjanjikan kepada pekerja yang upahnya ditetapkan berdasarkan hasil pekerjaan yang dilakukan;

7. Apabila majikan dengan jalan lain secara keterlaluan melalaikan kewajiban yang dibebankan kepadanya oleh perjanjian;

8. Apabila majikan dalam hal hubungan kerja tidak mencakupnya, menyuruh pekerja meskipun telah ditolak, untuk melakukan pekerjaan di perusahaan seorang majikan yang lain;

9. Apabila terus berlangsungnya hubungan kerja bagi pekerja dapat menimbulkan bahaya besar yang mengancam jiwa, kesehatan, kesusilaan atau nama baiknya yang tidak terlihat pada waktu pembuatan perjanjian kerja;

10. Apabila pekerja karena sakit atau alasan di luar kesalahannya menjadi tidak mampu melakukan pekerjaan yang diperjanjikan.

Menurut Johan Suprihanto faktor penyebab terjadinya PHK dari pihak Pekerja/Buruh antara lain: ${ }^{17}$

1. Secara sukarela pekerja pindah pekerjaan karena adanya alasan lain;

2. Secara sukarela karena tidak adanya kepuasan kerja;

3. Membuat ulah agar hubungan kerjanya diputuskan karena tidak adanya kepuasan kerja.

Pemutusan Hubungan Kerja yang ketiga yaitu PHK oleh Pengadilan, dalam hal ini pihak majikan dan pekerja berwenang berdasarkan alasan penting mengajukan permintaan tertulis kepada Pengadilan Negeri di tempat kediamannya yang sebenarnya untuk menyatakan perjanjian kerja putus. Pemutusan Hubungan Kerja yang dilakukan Pengadilan atas permintaan pihak majikan dengan sendirinya tidak memerlukan izin dari Panitia Penyelesaian Perselisihan Perburuhan. ${ }^{18}$ Terhadap putusan Pengadilan Negeri

17 John Suprihanto, Hubungan Industrial Sebuah Pengantar (Yogyakarta: BPFE Yogyakarta, 2002), 118.

18 Ramly, Hukum Ketenagakerjaan, 46. 
tersebut tidak ada jalan untuk melawannya, dengan tidak mengurangi wewenang Jaksa Agung untuk semata-mata demi kepentingan Undang-Undang, mengajukan permintaan kasasi terhadap putusan tersebut PHK jenis ini sendiri dapat terjadi dengan alasan/sebab:

a. PHK karena perusahaan pailit (berdasarkan putusan Pengadilan Niaga) yang lebih lanjutnya dijelaskan dalam Pasal 165 UU Ketenagakerjaan;

b. PHK terhadap anak yang tidak memenuhi syarat untuk bekerja yang digugat melalui lembaga PPHI sesuai dengan pengaturan Kesehatan dan Keamanan Kerja yang dimana pekerja anak dan perempuan diatur lebih khusus daripada pekerja laki-laki, sebab kedua ini dijelaskan lebih lanjut pada Pasal 165 UU Ketenagakerjaan;

c. PHK karena berakhirnya PK yang selanjutnya dijelaskan dalam Pasal 154 huruf b kalimat kedua.

Sedangkan jenis keempat adalah Pemutusan Hubungan Kerja oleh pengusaha yaitu PHK oleh pengusaha yang terjadi karena keinginan dari pihak pengusaha dengan alasan persyaratan dan prosedur tertentu. Menurut Johan Suprihanto penyebab terjadinya PHK dari pihak pengusaha, antara lain:19

1. Pelanggaran disiplin oleh pekerja;

2. Mempunyai itikad tidak baik (unfair labour practices);

3. Akibat perselisihan antara pekerja dan pengusaha;

4. Terjadinya perubahan tata kerja perusahaan;

5. Keadaan perusahaan;

6. Secara tidak langsung, kebijakan pemerintah dalam hal-hal tertentu yang mengakibatkan PHK.

Pemberhentian berdasarkan keinginan perusahaan dapat terjadi karena karyawan tersebut berusia lanjut. Karena karyawan tersebut sudah berusia lanjut, maka dalam bekerja kurang cakap atau melakukan tindakan yang merugikan seperti korupsi. Keinginan perusahaan memberhentikan karyawan ini disebabkan: ${ }^{20}$

1. Karyawan tidak mampu mengerjakan pekerjaannya;

2. Perilaku dan kedisiplinannya kurang baik;

3. Melanggar peraturan dan tata tertib perusahaan;

4. Tidak dapat bekerja sama dan konflik dengan karyawan lainnya;

5. Melakukan tindakan amoral dalam perusahaan.

Faktor penyebab pemutusan hubungan kerja secara yuridis dalam Undang-Undang Nomor 13 Tahun 2003, yang mana PHK dilakukan oleh perusahaan disebabkan:

9 Ibid.

20 Nikodemus Maringan, "Tinjauan Yuridis Pelaksanaan Pemutusan Hubungan Kerja (PHK) Secara Sepihak oleh Perusahaan Menurut Undang-undang No. 13 Tahun 2003 Tentang Ketenagakerjaan," Legal Opinion 3, no. 13 (2015): 1-10. 
1. Perusahaan mengalami kemunduran sehingga perlu rasionalisasi atau pengurangan jumlah pekerja/buruh. Dalam hal PHK dengan alasan rasionalisasi atau kesalahan ringan pekerja/buruh dalam UU Ketenagakerjaan, Pasal 151 ayat (1) ditentukan bahwa pengusaha, pekerja, serikat pekerja, dan pemerintah berupaya mengusahakan agar tidak terjadinya PHK. Dalam hal, upaya tersebut telah dilakukan, tetapi PHK tidak dapat dihindari, maka maksud PHK wajib dirundingkan oleh perusahaan dan SP/SB atau pekerja, apabila pekerja tidak menjadi anggota SP/SB.

2. Pekerja telah melakukan kesalahan, baik kesalahan melanggar ketentuan yang tercantum dalam peraturan perusahaan, perjanjian kerja atau PKB (Kesalahan ringan), maupun kesalahan pidana (kesalahan berat). Pekerja yang diputuskan hubungan kerja karena pekerja telah melakukan kesalahan berat hanya akan memperoleh uang penggantian hak. Dalam hal ini pemerintah mengatur dengan tegas faktor penyebab terjadinya PHK dengan harapan agar pengusaha tidak melakukan PHK secara semena-mena terhadap pekerja dan juga tidak melanggar hak pekerja, sebagaimana yang tercantum dalam Pasal 153 ayat (1) poin ke (3) UU Ketenagakerjaan adanya larangan pemberlakuan PHK yaitu pekerja yang bersangkutan menjalankan ibadah yang diperintahkan oleh agamanya. ${ }^{21}$

PHK ini diatur dalam Pasal 158 Undang-Undang Nomor 13 Tahun 2003 Tentang Ketenagakerjaan. Dalam Pasal 158 sendiri salah satu alasan dilakukannya Pemutusan Hubungan Kerja adalah karena adanya kesalahan berat yang dilakukan oleh pekerja, namun dalam UU Ketenagakerjaan sendiri tidak menjelaskan lebih lanjut kriteria kesalahan berat itu sendiri. Sehingga hal ini dirasa bertentangan dengan Pasal 27 ayat (1) UUD 1945 serta melanggar asas praduga tidak bersalah (preassumption of innocence) maka dalam hal ini Mahkamah Konstitusi menjatuhkan Putusan No.012/PUU-1/2003 yang menyatakan ketentuan Pasal 158 UU Ketenagakerjaan bertentangan dengan UUD 1945 dan tidak mempunyai kekuatan hukum yang mengikat.

Dalam Pemutusan Hubungan Kerja oleh Pengusaha sendiri tentunya memiliki syaratsyarat tertentu agar Perusahaan dapat melakukan PHK kepada pekerjanya, syarat-syarat ini dijelaskan dalam Pasal 153 UU Ketenagakerjaan, yang dimana dalam ayat (2)-nya berbunyi "(2) Pemutusan Hubungan kerja yang dilakukan dengan alasan sebagaimana dimaksud dalam ayat (1) batal demi hukum dan pengusaha wajib memperkerjakan kembali pekerja/buruh yang bersangkutan."

Dalam Pemutusan Hubungan Kerja yang dilakukan oleh Perusahaan tentunya harus memenuhi syarat-syarat agar dapat melakukan PHK terhadap pekerjanya sendiri, yaitu

\begin{tabular}{lll}
\hline No. & $\begin{array}{c}\text { Alasan Terjadinya Pemutusan Hubungan } \\
\text { Kerja }\end{array}$ & \multicolumn{1}{c}{ Syarat Pemutusan Hubungan Kerja } \\
\hline 1 & Masa Percobaan & Dalam periode masa percobaan \\
2 & Melakukan tindak pidana & - Perbuatan diatur dalam PP/PKB \\
& & - Cukup alat bukti, proses Biparti, Mediasi, PHI \\
& & dan/atau
\end{tabular}

21 Ibid. 
3 Penahanan lebih dari 6 (enam) bulan

4 Belum 6 (enam) bulan ditahan dinyatakan bersalah

5 Melanggar Perjanjian Kerja Peraturan Perusahaan/PKB, kualifikasi ringan, sedang dan pengulangan

6 Mengundurkan diri

7 Karyawan menolak melanjutkan hubungan kerja akibat perubahan status, penggabungan atau peleburan

Pengusaha menolak melanjutkan hubungan kerja akibat perubahan status, penggabungan atau peleburan

Perusahaan tutup, karena mengalami kerugian 2(dua) tahun berturut-turut

10 Perusahaan tutup, tidak karena mengalami kerugian

11 Perusahaan Pailit

12 Meninggal Dunia

13 Pensiun

14 Mangkir

15 Pekerja telah salah atau keliru menuduh Pengusaha melakukan perbuatan yang bertentangan dengan Undang-Undang, tidak membayar upah 3 bulan berturut-turut, tidak melaksanakan kewajiban, memerintahkan pekerjaan di luar yang diperjanjikan, memberikan pekerjaan yang membahayakan jiwa, keselamatan dan kesehatan
- Cukup alat bukti proses pidana (kepolisian, kejaksaan, pengadilan negeri)

- Putusan pidana pengadilan yang berkekuatan hukum tetap

Dibuktikan dengan surat penahanan, penahanan melampaui batas 6 (enam) bulan

Putusan pidana pengadilan tingkat pertama/pengadilan negeri

- Surat peringatan I, II, dan III; atau

- Proses PHK (berdasarkan bobot pelanggaran).

1. Permohonan 30 hari sebelumnya;

2. Tidak dalam ikatan dinas;

3. Tetap bekerja sampai tanggal efektif.

Tidak ada job security dari perusahaan atau TUPE (Transfer Undertaking of Protection of Employee)

Menyampaikan secara tertulis penolakannya disertai alasan pada periode yang ditetapkan setelah diumumkannya proses perubahan status, penggabungan atau peleburan yang dilakukan perusahaan

Tidak ada job security dari perusahaan atau TUPE (Transfer Undertaking of Protection of Employee) Terjadi kelebihan karyawan akibat perubahan status, penggabungan atau peleburan Reorganisasi atau Restrukturisasi perusahaan Menyampaikan secara tertulis penolakannya disertai alasan pada periode yang ditetapkan setelah diumumkannya proses perubahan status, penggabungan atau peleburan yang dilakukan perusahaan

Laporan keuangan dua tahun berturut-turut dari akuntan publik

$\mathrm{PP} / \mathrm{PKB}$ mengatur alasan reorganisasi atau restrukturisasi atau kelebihan pekerjaan atau Perusahaan tutup permanen

Putusan pailit pengadilan niaga yang berkekuatan hukum tetap

Surat Kematian

Usia pensiun yang ditetapkan perusahaan

Tidak masuk kerja 5 (lima) hari berturut-turut tanpa pemberitahuan

Panggilan untuk masuk kerja dua kali

Putusan pengadilan Hubungan Industrial atau hasil pemeriksaan pengadilan apabila diajukan gugatan balik/rekonvensi

Karya Tulis ini akan berfokus membahas tentang Pemutusan hubungan kerja akibat pandemi, seperti yang dijelaskan di atas tentang syarat-syarat suatu perusahaan dapat melakukan pemutusan hubungan kerja yang kebanyakan karena adanya kesalahan dari pekerjanya sendiri. Namun dalam masa pandemi ini, perusahaan melakukan PHK tanpa 
adanya kesalahan dari pekerja. Hal ini merupakan suatu kebijakan perusahaan yang sangat mungkin terjadi dan pasti ada beberapa perusahaan yang telah melakukannya. Ditambah dalam hal ini Pemerintah telah menetapkan COVID-19 sebagai bencana nasional melalui Keputusan Presiden Nomor 12 Tahun 2020 (Keppres Bencana Nasional). Karena ditetapkannya Keppres ini maka diperbolehkanlah Perusahaan melakukan Pemutusan Hubungan Kerja, dengan syarat harus membayar uang pesangon, uang masa kerja, dan uang penggantian hak yang seharusnya diterima. Dalam Pemutusan Hubungan Kerja ini pasal yang dapat digunakan adalah Pasal 164 ayat (3) UU Ketenagakerjaan dengan alasan efisiensi. Karena terdapat dua syarat dalam Pemutusan Hubungan Kerja yaitu Perusahaan tutup karena rugi atau force majeur yang diatur dalam Pasal 164 ayat (1) UU Ketenagakerjaan, dan alasan kedua perusahaan melakukan Pemutusan Hubungan Kerja karena efisiensi yang dijelaskan lebih lanjut dalam Pasal 164 ayat (3) UU Ketenagakerjaan. ${ }^{22}$

(1) "Pengusaha dapat melakukan pemutusan hubungan kerja terhadap pekerja/buruh karena perusahaan tutup yang disebabkan perusahaan mengalami kerugian secara terus menerus selama 2 (dua) tahun, atau keadaan memaksa (force majeur), dengan ketentuan pekerja/buruh berhak atas uang pesangon sebesar 1 (satu) kali ketentuan Pasal 156 ayat (2) uang penghargaan masa kerja sebesar 1 (satu) kali ketentuan Pasal 156 ayat (3) dan uang penggantian hak sesuai ketentuan Pasal 156 ayat (4)."

(3) "Pengusaha dapat melakukan pemutusan hubungan kerja terhadap pekerja/buruh karena perusahaan tutup bukan karena mengalami kerugian 2 (dua) tahun berturut-turut atau bukan karena keadaan memaksa (force majeur) tetapi perusahaan melakukan efisiensi, dengan ketentuan pekerja/buruh berhak atas uang pesangon sebesar 2 (dua) kali ketentuan Pasal 156 ayat (2), uang penghargaan masa kerja sebesar 1 (satu) kali ketentuan Pasal 156 ayat (3) dan uang penggantian hak sesuai ketentuan Pasal 156 ayat (4)."

Untuk kewajiban membayar uang pesangon sendiri perusahaan harus membayar uang pesangon kepada pekerja yang di PHK, pengertian uang pesangon sendiri adalah uang ganti rugi akibat pemutusan hubungan kerja ini sendiri. Dalam kewajiban pertama ini sudah ditentukan cara penghitungannya dalam Pasal 156 ayat (2) UU Ketenagakerjaan yaitu:

“(2) Perhitungan uang pesangon sebagaimana dimaksud dalam ayat (1) paling sedikit sebagai berikut:

a. Masa kerja kurang dari 1 (satu) tahun, 1 (satu) bulan upah;

b. Masa kerja 1 (satu) tahun atau lebih tetapi kurang dari 2 (dua) tahun, 2 (dua) bulan upah;

c. $\quad$ Masa kerja 2 (dua) tahun atau lebih tetapi kurang dari 3 (tiga) tahun, 3 (tiga) bulan upah;

d. $\quad$ Masa kerja 3 (tiga) tahun atau lebih tetapi kurang dari 4 (empat) tahun, 4 (empat) bulan upah;

22 Ibid. 
e. $\quad$ Masa kerja 4 (empat) tahun atau lebih tetapi kurang dari 5 (lima) tahun, 5 (lima) bulan upah;

f. $\quad$ Masa kerja 5 (lima) tahun atau lebih, tetapi kurang dari 6 (enam) tahun, 6 (enam) bulan upah;

g. Masa kerja 6 (enam) tahun atau lebih, tetapi kurang dari 7 (tujuh) tahun, 7 (tujuh) bulan upah;

h. Masa kerja 7 (tujuh) tahun atau lebih tetapi kurang dari 8 (delapan) tahun, 8 (delapan) bulan upah;

i. Masa kerja 8 (delapan) tahun atau lebih, 9 (sembilan) bulan upah."

Kewajiban perusahaan yang kedua yaitu memberi uang masa kerja, pekerja yang sudah bekerja minimal 3 tahun di sebuah perusahaan berhak mendapatkan uang masa kerja. Uang masa kerja ini sendiri diatur dalam Pasal 156 ayat (3) UU Ketenagakerjaan,

“(3) Perhitungan uang penghargaan masa kerja sebagaimana dimaksud dalam ayat (1) ditetapkan sebagai berikut:

a. Masa kerja 3 tahun atau lebih tetapi kurang dari 6 tahun, 2 bulan upah;

b. Masa kerja 6 tahun atau lebih kurang dari 9 tahun, 3 bulan upah;

c. Masa kerja 9 tahun atau lebih kurang dari 12 tahun, 4 bulan upah;

d. Masa kerja 12 tahun atau lebih kurang dari 15 tahun, 5 bulan upah;

e. Masa kerja 15 tahun atau lebih tetapi kurang dari 18 tahun, 6 bulan upah;

f. Masa kerja 18 tahun atau lebih tetapi kurang dari 21 tahun, 7 bulan upah;

g. Masa kerja 21 tahun atau lebih tetapi kurang dari 24 tahun, 8 bulan upah;

h. Masa kerja 24 tahun atau lebih, 10 bulan upah."

Kewajiban perusahaan selanjutnya adalah uang penggantian hak, uang penggantian hak ini telah diatur dalam Pasal 156 ayat (4) UU Ketenagakerjaan yaitu,

"(4) Uang penggantian hak yang seharusnya diterima sebagaimana dimaksud dalam ayat (1) meliputi:

a. Cuti tahunan yang belum diambil dan belum gugur;

b. Biaya atau ongkos pulang untuk pekerja/buruh dan keluarganya ke tempat dimana pekerja/buruh diterima bekerja;

c. Penggantian perumahan serta pengobatan dan perawatan ditetapkan $15 \%$ dari uang pesangon dan atau uang penghargaan masa kerja bagi yang memenuhi syarat;

d. Hal-hal lain yang ditetapkan dalam perjanjian kerja, peraturan perusahaan atau perjanjian kerja bersama."

Ketiga kewajiban perusahaan saat melakukan PHK ini ditetapkan dalam Peraturan Pemerintah. Dan bilamana perusahaan tidak melakukan kewajibannya maka perusahaan dapat dilaporkan ke pihak yang berwenang, hal ini sesuai dengan Pasal 111 ayat (2) UU Ketenagakerjaan bahwasanya peraturan perusahaan yang bertentangan dengan undangundang dianggap batal demi hukum. Sehingga yang berlaku adalah ketentuan yang ada di dalam Undang-Undang, yang mana dalam hal ini dapat kita ketahui bahwa perusahaan wajib melakukan kewajibannya saat melakukan PHK terhadap pekerjanya sehingga hakhak para pekerja tetap terpenuhi dan dilindungi hukum. 
Kemudian berdasarkan Surat Edaran (SE) Menteri Ketenagakerjaan Nomor M/3/HK04/III/2020 Tentang perlindungan pekerja dan kelangsungan usaha dalam rangka pencegahan dan penanggulangan COVID-19 dengan ketentuan sebagai berikut:

a) Bagi pekerja/buruh yang dikategorikan sebagai ODP (Orang Dalam Pengawasan) COVID-19 berdasarkan keterangan dokter sehingga tidak dapat masuk kerja paling lambat 14 (empat belas) hari sesuai standar Menteri Kesehatan maka upahnya dibayar penuh;

b) Bagi pekerja/buruh yang dikategorikan kasus korban COVID-19 dan di karantina/di isolasi menurut keterangan dokter maka upahnya dibayar secara penuh selama masa di karantina atau di isolasi;

c) Bagi pekerja/buruh yang tidak masuk kerja karena sakit akibat COVID-19 dan dibuktikan dengan keterangan dokter maka upahnya dibayar sesuai dengan peraturan perundang-undangan yang berlaku; dan

d) Bagi pengusaha yang melakukan pembatasan kegiatan usaha akibat kebijakan pemerintah di daerah masing-masing guna pencegahan dan penanggulangan COVID19 sehingga menyebabkan sebagian atau seluruh pekerja/buruh tidak masuk kerja dengan mempertimbangkan kelangsungan usaha maka perubahan besaran maupun cara pembayaran upah pekerja dilakukan sesuai kesepakatan antara pengusaha dan pekerja.

Dalam hal COVID-19 sudah ditetapkan oleh pemerintah sebagai bencana nasional dengan ditetapkannya Keppres Nomor 12 Tahun 2020 ini tidak serta merta dapat di jadikan alasan force majeur karena inti dari force majeur sendiri yaitu tidak bisa dilaksanakannya prestasi karena terhalang suatu keadaan yang memaksa. Force majeur sendiri digunakan ketika prestasi sama sekali tidak dapat dipenuhi, dan force majeur dapat diterapkan karena kondisi nyata halangan melaksanakan kewajiban dalam perjanjian bukan karena status darurat bencana nasional yang telah ditetapkan oleh Pemerintah. Sedangkan Pemutusan Hubungan Kerja akibat COVID-19 di Indonesia rata-rata melakukan PHK bukan karena perusahaannya tutup atau pailit, melainkan karna diberlakukannya Work From Home yang merupakan anjuran dari Pemerintah. Dalam hal ini maka masih dapat dilakukan sebuah prestasi namun hanya saja waktunya tidak sesuai dengan yang diperjanjikan. Sedangkan dalam force majeur yang dijelaskan dalam Pasal 1245 KUHPer yang mengatur tentang penggantian biaya kerugian dan bunga dapat dimaafkan bilamana terjadi suatu keadaan yang memaksa, namun bukan hanya Pasal 1245 KUHPer saja persyaratan agar dapat mengajukan force majeur, force majeur juga harus dapat dibuktikan bahwa memang benar terjadi halangan yang betul-betul membuat prestasinya tidak dapat dilakukan.

Hardship sendiri merupakan metode kontraktual yang cukup canggih dalam menangani persoalan terjadinya perubahan keadaan fundamental yang akan mempengaruhi hakikat dari perjanjian para pihak. Biasanya klausul hardship ini digunakan dalam kontrakkontrak jangka panjang yang nilainya tinggi. Maksudnya ialah untuk mengatasi kesulitan yang dalam penerapan isi kontrak termasuk keadaan memaksa dan doktrin kegagalan 
(frustration). Dalam kondisi pandemi ini sendiri perlu ditinjau dari perspektif lain, seperti apakah kesulitan tersebut bersifat kasuistik saja, atau ternyata kesulitan yang terjadi (seperti kesulitan keuangan, kemiskinan, sakit parah, dll) merupakan hal yang terjadi secara meluas sebagai akibat dari Pandemi COVID-19 sehingga memang tidak patut bagi pihak terdampak untuk menanggung kerugian, hal ini dapat menjadi pertimbangan oleh hakim. ${ }^{23}$

Adapun ketentuan hardship diatur dalam Pasal 6.2.2 The Unidroit Principles memiliki unsur-unsur sebagai berikut:

Pertama, adanya peristiwa yang secara fundamental mengubah keseimbangan.

Kedua, peristiwanya terjadi atau baru diketahui oleh pihak yang dirugikan setelah perjanjian disepakati.

Ketiga, peristiwanya secara rasional tidak diprediksi pada saat perjanjian disepakati.

Keempat, peristiwanya di luar kontrol pihak yang dirugikan.

Kelima, risiko dari peristiwa yang terjadi diduga oleh pihak yang dirugikan.

Hal yang memperkuat argumen ini adalah, pada Pasal 164 ayat (1), Pasal ini menjelaskan keadaan yang masuk ke dalam force majeur contohnya adalah peperangan, kerusuhan, revolusi, bencana alam, pemogokan, kebakaran, dalam hal ini bencana non alam tidak masuk ke dalam force majeur. Sedangkan dalam Pasal 164 ayat (3) pengusaha dapat melakukan PHK terhadap pekerja karena perusahaan ingin melakukan efisiensi, dalam hal ini sebelum melakukan PHK perusahaan harus melakukan beberapa upaya, yakni:

1. Mengurangi upah dan fasilitas pekerja, contohnya tingkat manajer dan direktur upah dan fasilitasnya dikurangi;

2. Mengurangi waktu kerja shift;

3. Membatasi atau meniadakan waktu kerja lembur;

4. Mengurangi jam kerja;

5. Mengurangi hari kerja;

6. Tidak memperpanjang kontrak pekerja yang sudah berakhir;

7. Memberikan pensiun bagi pekerja yang sudah memenuhi syarat.

Sebelumnya sudah dijelaskan tentang Hardship maupun Force Majeur. Dalam Pemutusan Hubungan Kerja ini, tentunya prestasi yang dimaksud adalah dengan cara perusahaan memberikan upah bagi pekerjanya, dan bila mana perusahaan tidak mampu membayar pekerjanya, maka dianggap bahwa perusahaan telah melakukan wanprestasi. Dan Pemutusan Hubungan Kerja dapat dilakukan perusahaan, bilamana perusahaan sesuai dengan Pasal 164 ayat (3) UU 13/2003, Perusahaan melakukan pembayaran pesangon kepada pekerja sebesar 2 (dua) kali ketentuan Pasal 156 ayat (2).

23 Irma Devita, "Mengetahui Akibat dan Risiko Perjanjian Force Majeure," Irmadevita.com, last modified 2020, diakses Juni 28, 2020, https://irmadevita.com/2020/mengetahui-akibat-dan-risiko-perjanjianforce-majeure/. 


\section{Penutup}

Suatu keadaan dapat dikatakan sebagai keadaan force majeur apabila keadaan tersebut memaksa pada suatu peristiwa yang tidak pasti dan tidak dapat diduga sebelumnya yang terjadi setelah kontrak ditutup dan menghalangi pihak debitur dalam memenuhi prestasi atau kewajibannya baik seluruh maupun sebagai dan kepadanya tidak dapat di dipersalahkan. Suatu Keadaan dapat dikatakan sebagai keadaan hardship apabila peristiwa tersebut tidak pasti yang tidak dapat diduga sebelumnya yang terjadi setelah kontrak ditutup yang membuat debitur kesulitan dalam memenuhi kewajibannya, dan akan mengalami kerugian manakala debitur tetap memenuhi kewajibannya, debitur tetap berada dalam keadaan wanprestasi jika ia tidak memenuhi kewajibannya. Pemutusan hubungan kerja pada masa COVID-19 pada hakikatnya sesuai dengan ketentuan, dikarenakan COVID-19 secara fundamental mengubah keseimbangan, COVID-19 ini baru diketahui oleh pihak yang dirugikan setelah perjanjian setelah disepakati, peristiwa COVID-19 secara rasional tidak diprediksi saat perjanjian disepakati, keadaan COVID-19 juga di luar kontrol pihak yang dirugikan. Sedangkan solusi yang penulis berikan dalam tulisan yaitu perusahaan yang memutus hubungan kerja sebaiknya diganti dengan menunda kerja biasa atau renegosiasi kontrak dikenal dengan istilah hardship, memang sebagai negara yang menganut sistem hukum civil law, Indonesia tidak mengenal klausul hardship. Setiap perubahan keadaan diselesaikan dengan konsep force majeure. Tapi yang menjadi masalah adalah bahwa kekuatan konsep force majeure tidak dapat membantu para pekerja untuk melanjutkan Pekerjaan. Bersandarkan pada prinsip kebebasan kontrak, klausul hardship dapat digunakan untuk mempertahankan pelaksanaan kontrak dalam kaitannya dengan para pekerja yang terkena dampak COVID-19 ini. Dalam keadaan COVID-19 ini, para pihak akan melakukan renegosiasi kontrak untuk menentukan penyesuaian kontrak pekerjaan terkait dengan perubahan yang terjadi. Jika negosiasi ulang ini tidak ada membuahkan hasil, salah satu pihak dapat mengajukan sengketa ini ke pengadilan yang telah ditentukan dalam kontrak kerja. Itulah sebabnya klausul hardship sangat penting dalam keadaan ini karena konsep ini sudah berdasarkan asas keadilan dan kepastian hukum bagi para buruh terkena pemutusan hubungan kerja akibat COVID-19 ini.

\section{Daftar Pustaka}

Adi, Dwi Prilmilono. “Absorbsi Prinsip 'Rebus Sic Stantibus' dalam Kerangka Pembaharuan Hukum Perjanjian Nasional." Jurnal Hukum Jatiswara (2015): 71-91.

Arnani, Mela. “Timeline Wabah Virus Corona, Terdeteksi pada Desember 2019 hingga Jadi Pandemi Global." Kompas.com. Last modified 2020. Diakses Mei 18, 2020. https://www.kompas.com/tren/read/2020/03/12/113008565/timeline-wabahvirus-corona-terdeteksi-pada-desember-2019-hingga-jadi.

Buwana, Sudibyo Aji Narendra, dan Mario Septian Adi Putra. "Implementasi Pemutusan Hubungan Kerja (PHK) Terhadap Pekerja Status Perjanjian Kerja Waktu Tertentu (PKWT) PADA PT X DI KOTA MALANG." Jurnal Studi Manajemen 9, no. 5 (2015): 202- 
214.

Devita, Irma. "Mengetahui Akibat dan Risiko Perjanjian Force Majeure." Irmadevita.com. Last modified 2020. Diakses Juni 28, 2020. https://irmadevita.com/2020/mengetahui-akibat-dan-risiko-perjanjian-forcemajeure/.

Fuady, Munir. Konsep Hukum Perdata. Jakarta: Rajawali Pers, 2015.

Hadi, Abdul. "Fenomena Menikah Dengan Teman Sekantor Pasca Putusan Mahkamah Konstitusi Tentang Uji Materi Pasal 153 Ayat (1) Huruf F Undang-Undang Nomor 13 Tahun 2003 Tentang Ketenagakerjaan." Jurnal Surya Kencana Dua: Dinamika Masalah Hukum dan Keadilan 5, no. 1 (2018): 352-368.

Ishaq, H. Metode Penelitian Hukum dan Penulisan Skripsi Tesis Serta Disertasi. Bandung: Alfabeta, 2017.

Kasim, Umar. "Hubungan Kerja dan Pemutusan Hubungan Kerja.” Informasi Hukum. Last modified 2004. Diakses Agustus 2020. http://web.archive.org/web/20041230083336/http://www.nakertrans.go.id/maja lah_buletin/info_hukum/vol2_vi_2004/phk.php.

Maringan, Nikodemus. "Tinjauan Yuridis Pelaksanaan Pemutusan Hubungan Kerja (PHK) Secara Sepihak oleh Perusahaan Menurut Undang-undang No. 13 Tahun 2003 Tentang Ketenagakerjaan." Legal Opinion 3, no. 13 (2015): 1-10.

Muhammad, Abdulkadir. Hukum dan Penelitian. Bandung: Citra Aditya Bakti, 2004.

Priyono, Ery Agus. "Aspek Keadilan dalam Kontrak Bisnis di Indonesia (Kajian pada Perjanjian Waralaba)." Law Reform 14, no. 1 (2018): 15.

Ramly, Lanny. Hukum Ketenagakerjaan. Surabaya: Airlangga University Press, 2008.

Simamora, Yohanes Sogar. Prinsip-prinsip Hukum Kontrak Pengadaan Barang dan Jasa Pemerintah di Indonesia. Yogyakarta: Laksbang Pressindo, 2017.

Soekanto, Soerjono. Penelitian Hukum Normatif. Jakarta: RajaGrafindo Persada, 2006.

Soepomo, Iman. Pengantar Hukum Perburuhan. Jakarta: Djambatan, 1999.

Sunindhia, Y. W., dan Ninik Widiyanti. Masalah Pemutusan Hubungan Kerja dan Mogok. Jakarta: Bina Aksara, 1996.

Suprihanto, John. Hubungan Industrial Sebuah Pengantar. Yogyakarta: BPFE Yogyakarta, 2002.

World Health Organization. "Naming the Coronavirus Disease (COVID-19) and the Virus that Causes It." World Health Organization. Last modified 2020. Diakses Mei 18, 2020. https://www.who.int/emergencies/diseases/novel-coronavirus-2019/technicalguidance/naming-the-coronavirus-disease-(covid-2019)-and-the-virus-that-causesit. 